\title{
Globalizing Racism and De-Provincializing Muslim Africa ${ }^{1}$
}

"One of the paradoxes of history is that it took Africa's contact with the Arab world to make the Black people of Africa realize that they were black in description, but not necessarily in status... On the other hand, it took European conceptualization and cartography to turn Africa into a continent."

-Ali A. Mazrui, "The Re-Invention of Africa: Edward Said, V. Y. Mudimbe, and Beyond," Research in African Literatures 36/3 (2005), 68-82, at 70.

Historians of Africa can no longer overlook race. To scholars of African Diaspora studies (who often work under the rubric of Africana studies, Black studies, and African-American studies), the recognition of this fact is long overdue. ${ }^{2}$ With the rise of the area-studies paradigm in the 1950s, North American scholars of Africa became preoccupied with the rise of nationalism and the writing or critique of national histories. The future was defined by national development, while the study of the past was centered on the search for a pristine precolonial identity. ${ }^{3}$ Consequently, a world of nations took precedence in scholarly writing over concerns about the management of empires, colonies and, strikingly, races. Even as Africanist scholars came to reevaluate the successes and failures of the postcolonial experience across Africa in the 1970s,

\footnotetext{
${ }^{1}$ We would like to thank Wendell Hassan Marsh, Cheikh Babou, Adrienne Brown, Jonathan AC Brown, Debjani Bhattacharyya, Clifford Crais, Jeremy Dell, Adom Getachew, Sean Hanretta, Jemima Pierre, Erin Pettigrew, Noah Salomon, Tehila Sasson, Anisha Thomas and Rasul Miller for their careful readings of the manuscript in its different stages. We also had the good fortune to present the paper on numerous occasions, including at the $60^{\text {th }}$ African Studies Association Meeting, Emory University, the University of Chicago and at a conference the authors organized at the University College, London entitled Bridging the Divide Between African Diaspora Studies and African Studies: A Critical Workshop in 2019. I would also like to thank the editors at Modern Intellectual History including Tracie Matysik and Daniel Steinmetz-Jenkins as well as the anonymous reviewers.

${ }^{2}$ African-American scholars have long addressed African history within the broader study of modern racism. See, for example, W. E. B. Du Bois, The World and Africa: An Inquiry into the Part which Africa has Played in World History (New York, 1947).

${ }^{3}$ John Ralph Willis, "The Historiography of Islam in Africa: The Lost Decade (1960-1970)," African Studies Review, 14/3 (1971), 403-24.
} 
they frequently lamented the persistence of ethnic conflict, but not of ongoing forms of racial hierarchy. Race, insofar as it was treated at all, tended to be confined to the "colonial episode" and to settler states, like South Africa. ${ }^{4}$

In recent years, however, historians of Africa have begun to address this lacuna. Some of the most exciting work on race has centered on Muslim African societies. Scholars such as Chouki El Hamel, Eve Troutt Powell, Bruce Hall, Jonathon Glassman, and Michael Gomez have shown that it is possible to write intellectual and cultural histories of race without rendering them derivative of the European experience. Coming from a range of fields--including African History, Islamic Studies, Middle Eastern Studies and African Diaspora Studies--they have examined processes of racialization in different regions of North, West, and East Africa. These historians have argued that racism is not a purely Euro-American invention and have traced distinct genealogies of race and racism in Muslim Africa. ${ }^{5}$

This scholarship has opened up new and expansive conceptual, theoretical, and empirical ground. It has broadened our understanding of the roots of anti-black prejudice, moving beyond a black/white dualism at the heart of colonial scholarship and its critique. It has also helped decenter the colonial state, further revealing the importance of precolonial and postcolonial African intellectual history and opening space for historians of Africa to write about racialization in non-European and Atlantic World contexts. Studying the development of race and racism in Muslim Africa has the potential to de-naturalize and historicize the racial and geographic

\footnotetext{
${ }^{4}$ Jemima Pierre, The Predicament of Blackness: Postcolonial Ghana and the Politics of Race (Chicago, 2012). There is a rich body of scholarship on race in South Africa and other settler colonies in Africa. See also the large body of work in comparative race studies, such as Anthony Marx, Making Race and Nation: A Comparison of South Africa, the United States and Brazil (Cambridge, 1997).

${ }^{5}$ Eve Troutt Powell, A Different Shade of Colonialism: Egypt, Great Britain, and the Mastery of the Sudan (Berkeley, 2003); Bruce S. Hall, A History of Race in Muslim West Africa, 1600-1960 (Cambridge, 2011); Jonathon Glassman, War of Words, War of Stones: Racial Thought and Violence in Colonial Zanzibar (Bloomington, 2011); Chouki El Hamel, Black Morocco: A History of Slavery, Race, and Islam (Cambridge, 2013); Michael A. Gomez, African Dominion: A New History of Empire in Early and Medieval West Africa (Princeton, 2018).
} 
categories (including the very concept of "Sub-Saharan" Africa) that today underpin African studies. ${ }^{6}$

Beyond challenging the pervasive alterity of Sub-Saharan Africa and contributing to long-standing debates within critical race theory, new Africanist scholarship on race sets the stage for a much-needed and long-anticipated conversation between African studies, African Diaspora studies, and Islamic Studies. This is because, as we argue in this essay, instances of racialization in African Muslim societies are part and parcel of an overdetermined, global, longue durée historical process whose contours transcend various geographies and bridge disciplines that have long studied these areas or bodies of knowledge in isolation. The task awaiting historians is to determine how best to examine the mutual construction of racism across the Indian Ocean, Mediterranean, West African, and Atlantic worlds. Such a project entails not only considering the influence of Atlantic systems of race-making on Africa, but also tracing how West African, Mediterranean, and Indian Ocean societies shaped the Atlantic economy and its racialized culture. But it is necessary to remember that it is impossible to scrap away these histories of connectivity and interaction in order to reveal an Africa and its intellectual traditions of race that existed prior to the global encounter.

The intellectual history of race also sheds light on a question that has long occupied critical race theorists: under what circumstances does racial thinking become racism? As Eduardo Bonilla-Silva notes, the "mere existence of a racial discourse," does not necessarily indicate "the presence of a racial order." Sociologists, historians, and theorists of race have

\footnotetext{
${ }^{6}$ Clifford Geertz, Islam Observed: Religious Development in Morocco and Indonesia (New Haven, 1968); Edward W. Said, Orientalism (New York, 1978); V. Y. Mudimbe, The Invention of Africa Gnosis, Philosophy and the Order of Knowledge (Bloomington, 1988); and V. Y. Mudimbe, The Idea of Africa (Bloomington, 1994).

${ }^{7}$ Eduardo Bonilla-Silva, "Rethinking Racism: Toward a Structural Interpretation," American Sociological Review 62/3 (1997), 465-80.
} 
spilled much ink examining the links between the Atlantic World political economy, the intellectual antecedents of scientific racism, and the creation of a racial order that has normalized anti-blackness. Karen and Barbara Fields distinguish between race, racism, and what they define as "racecraft," a "mental terrain," a way of acting and imagining that shows "that racism has been on the scene." ${ }^{\prime 8}$ Studying anti-blackness in premodern and non-Atlantic World settings can enliven and enrich these debates while at the same time helping to delimit the very concept of racism. Yet, when applied too expansively, the term racism loses its critical resonance and renders anti-blackness into an ontological and transhistorical condition.

Writing the histories of race in Africa thus demands we recenter the continent within world history without rendering Africa derivative of a European story. As Steven Feierman has cautioned, African histories too often "survive merely as local color" within a broader metanarrative based on familiar Western concepts. ${ }^{9}$ To write a global history of racism without reinforcing Eurocentric and Atlantic world teleologies is to recognize that there are multiple, intertwined histories of race and that the dominance of nineteenth-century scientific racism was neither inevitable nor inexorable.

In order to understand and assess the conceptual novelty of the new histories of race in Muslim Africa, we make three interrelated arguments. First, we argue that the scholarly study of Africa in the North American academy has always been racialized. This racialization goes back to the very creation of Africa as an object of academic attention; and the need to equate Africa with blackness lies at the heart of Muslim Africa's liminality and North Africa's alterity. Rather

\footnotetext{
${ }^{8}$ Karen E. Fields and Barbara J. Fields, Racecraft: The Soul of Inequality in American Life (New York, 2014), 1819. Invoking the concept of witchcraft so often applied to anthropological understandings of Africa, they examine how Americans have come to accept fictitious concepts of race as seemingly rational and obvious.

${ }^{9}$ Steven Feierman, "Colonizers, Scholars, and the Creation of Invisible Histories," In Beyond the Cultural Turn: New Directions in the Study of Society and Culture, edited by V. Bonnell, L. Hunt, and R. Biernacki, 182-216, (Berkeley, 1999).
} 
than it being scholars' racialization of Africa that changes over time, it is the explicit mention of race that rises and falls during different periods of the professional study of Africa. Second, we argue that it is not possible to isolate an African intellectual tradition of race-making or racism. Of course, throughout history many Africans have thought with race and used it to pursue political and social power, but race is always relational and global. Therefore, we object to the idea that the intellectual traditions of race-thinking can be pursued in isolation. Third, we argue that though African history has been marked by many racial projects, these racial projects do not build seamlessly towards our contemporary ideas of race and racism. Finally, we believe that historians have to resist the temptation to consider the history of Muslim Africa a laboratory from which it is possible to peel back layers of European colonialism and Islamic hegemony in order to reveal a prior Africa isolated from global history.

\section{Africa as Part of the Study of Imperialism}

The anthropologist Jemima Pierre noted in 2012: "where African diaspora studies generally concerns itself with articulations of race and Blackness but not directly with Africa, so African studies generally concerns itself with Africa but not directly with race and Blackness."10 Since the 1950s, African Diaspora studies and African studies have existed in tension with one another. Though both disciplines were racialized, the former made race an explicit analytical framework and the latter sublimated the discussion of race.

The overlapping fields of Black studies, African-American studies, African Diaspora studies, Caribbean studies, and Africana studies have long been occupied with the problem of modern racism. Through research and debate around the links between capitalism, slavery, and

\footnotetext{
${ }^{10}$ Pierre, The Predicament of Blackness, xiv. For a useful review of Pierre's monograph, see: Benjamin Talton, "Race Politics in Ghana," Africa is a Country (January 18, 2013).
} 
race, generations of scholars of the African-American experience and the Atlantic world have worked to uncover the origins, development, and lasting effects of modern racism. ${ }^{11}$ Disciplinary concerns have been shaped by W.E.B. Du Bois' stunning and prescient statement that "the problem of the twentieth century is the problem of the color-line-the relation of the darker to the lighter races of men in Asia and Africa, in America and the islands of the sea." 12 Yet the portion of this statement that follows the hyphen, as Adom Getachew has pointed out has been largely ignored by later scholars. ${ }^{13}$ The bifurcation of fields allowed the breadth of Du Bois' geography to be neglected and for Africa to become relatively absent in discussions of race. ${ }^{14}$ However, this erasure has never been absolute and African Diaspora scholars, such as J. Lorand Matory, have long argued for the coevality of Africa and the African Diaspora. ${ }^{15}$

Since its emergence as a professional field in the late 1950s North American academy, African history has been structured by inherited and often-unspoken assumptions about race. The very contours of the discipline have been shaped by racialized conceptions of "black" Africa. The origins of these concepts in the North American academy go back to the eras of European exploration, slave-trading, abolitionist movements, and colonialism. Abolitionists like Sir Thomas Fowell Buxton were instrumental in crafting the image of a Black Africa that was the victim of the rapacious Turks, Moors and Arabs. In the process, abolitionists conceived of the

\footnotetext{
${ }^{11}$ Eric Williams, Capitalism and Slavery (Chapel Hill, 1944); James Sweet, "The Iberian Roots of American Racist Thought," The William and Mary Quarterly 54/1 (1997), 143-66.

${ }^{12}$ W.E.B. Du Bois, The Souls of Black Folk (Chicago, 1903), 45.

${ }^{13}$ Adom Getachew, Worldmaking After Empire: The Rise and Fall of Self-Determination (Princeton, 2019), 20.

14 "During the first decades of the twentieth century in the United States "international relations meant race relations," and the management of European empires based on racial hierarchies. Yet after the Second World War, North American scholars reimagined international politics as the relationship between independent states that were formally equal rather than the management of hierarchical empires. It was in this context that the study of Africa was gradually divorced from the study of the Black Diaspora." Robert Vitalis, White World Order, Black Power Politics: The Birth of American International Relations (Ithaca, 2017), 1.

${ }^{15}$ Matory has argued that in order to understand identity in the Black Diaspora it is necessary to focus on the interlinked histories and cross-fertilization between the continent and its diasporas. J.L. Matory, "The English Professors of Brazil: On the Diasporic Roots of the Yorùbá Nation," Comparative Studies in Society and History 41/ 1 (1999), 72-103.
} 
trans-Saharan slave trade as analogous to the Atlantic slave trade and helped to make North Africa (frequently treated as a neglected appendage of the Middle East) a strange lacuna within both African Studies long committed to the study of regions south of the Sahara and Middle Eastern Studies dominated by work on Western Asia and Egypt. ${ }^{16}$ A similar process occurred during the 1880s as French colonial theorists and practitioners put forward the ideas of "Islam noir."17 They drew, in particular, upon the Arabic distinction between bidan ("whites") and sudan ("blacks"). ${ }^{18}$ They also came to see sub-Saharan Islam as different from the putatively more pure, orthodox, and doctrinaire practices of Muslims further to the north and east. ${ }^{19}$ Over the last two decades, Africanist scholars have rejected the notion that there exists a distinct "African" Islam (that can be contrasted with “Arab” Islam). Yet only more recently have historians and anthropologists divested themselves of some of the residual assumptions underlying the theory of Islam Noir. This includes notions that African Islamic practices are more "adaptable" and "localized" than supposedly more universal traditions disseminating from

\footnotetext{
${ }^{16}$ E. Ann McDougall, "Discourse and Distortion: Critical Reflections on Studying the Saharan Slave Trades," Outre-Mers 89/336-337 (2002), 195-227; Ziad Bentahar, "Continental Drift: The Disjunction of North and subSaharan Africa," Research in African Literatures 42/1 (2011), 1-13; Ousmane Oumar Kane, Beyond Timbuktu: An Intellectual History of Muslim West Africa (Cambridge, 2016); Ousmane Oumar Kane, Non-Europhone Intellectuals (Dakar, 2012); Scott Reese ed., The Transmission of Learning in Islamic Africa (Leiden, 2004); Ghislaine Lydon and Baz Lecocq, "JAH Forum on Trans-Saharan Histories," Journal of African History 56/1 (2015): 3-36.

${ }^{17}$ Jean-Louis Triaud, "Islam in Africa under French Colonial Rule," In The History of Islam in Africa, edited by Nehemia Levitzion and Randall Pouwels, 169-188. (Athens, 2000) and Vincent Monteil, L'islam Noir: Une Religion à la Conquête de l'Afrique (Paris, 1908). For an example of Orientalist scholarship, see J. S. Trimingham, "The Arab Geographers and the East African Coast," In East Africa and the Orient: Cultural Syntheses in Pre-Colonial Times, edited by Hubert Neville Chittick and Robert I. Rotberg, 115-146. (New York, 1975).

${ }^{18}$ For more on the sudan/bidan distinction, see Wise, ed. The Desert Shore; James L. A. Webb, The Desert Frontier: Ecological and Economic Change Along the Western Sahel, 1600-1850 (University of Wisconsin Press, 1994); C.C. Stewart with E.C. Stewart, Islam and Social Order in Mauritania: A Case Study from the Nineteenth Century (Oxford: Clarendon Press, 1973); Abdel Wedoud Ould Cheikh, La société maure : éléments d'anthropologie historique (Centre des études sahariennes, 2017); Hall, A History of Race in West Africa; Ghislaine Lydon, On Trans-Saharan Trails: Islamic Law, Trade Networks, and Cross-Cultural Exchanges in Nineteenth Century Western Africa (Cambridge, Cambridge University Press, 2009). See also Noel King's introduction to Ibn Battuta, trans. by Hamdun and King, Ibn Battuta in Black Africa; and Gomez, African Dominion, 43-59, 144-167.

${ }^{19}$ Edmund Burke, The Ethnographic State: France and the Invention of Moroccan Islam (Berkeley, 2014), 34-5; Louis Brenner, "Histories of Religion in Africa," Journal of Religion in Africa 30/2 (2000), 166. One of the key purveyors of the theory of Islam noir was the military ethnographer Paul Marty, who served in Morocco, Tunisia, and the A.O.F. See, for example, Paul Marty, Etudes sur l'Islam et les Tribus du Soudan (Paris, 1917).
} 
the Middle East. Sean Hanretta cautions: "We should think seriously about jettisoning longstanding debates about how Islam 'changed' Africa or 'was changed' by Africans, as if it were a thing. For the formula 'Islam here is different but it is still Islam' relies ultimately on an essentialism that is both contradicted by the available evidence and deeply Arab-centric." ${ }^{20}$

One can see the discourse of Islam Noir as part and parcel of a broader process referred to by V. Y. Mudimbe as the "invention of Africa." ${ }^{21}$ Africa, as Mudimbe explains, is a concept largely derivative of Western intellectual traditions, which constructed the continent as Europe's "other." Yet the notion of black Africa's distinctiveness was not only a product of the European and colonial imagination. Many of these ideas were shaped by older North African, Arab and Islamic climactic and cartographic understandings of the world. ${ }^{22}$

Black Africa was also a concept embraced by many Pan-African thinkers, who saw the continent and its diaspora as sharing a common history and future. Nineteenth-century PanAfricanists such as Alexander Crummell, Edward Blyden, and W. E. B. Du Bois repurposed European notions of racial difference in order to valorize Africa and built upon an emerging global racial consciousness. Early Pan-Africanist ideas became key organizing frameworks for critiquing imperialism and white supremacy and mobilizing around a shared experience of slavery and racial colonialism. ${ }^{23}$ By the early twentieth century, peoples of African descent from

\footnotetext{
${ }^{20}$ Sean Hanretta, "Muslim Histories, African Societies: The Venture of Islamic Studies in Africa, Reviewed Work(s): Muslim Societies in African History by David Robinson; The History of Islam in Africa by Nehemia Levtzion and Randall L. Pouwels," The Journal of African History 46/3 (2005): 491. Similar characterizations of "South Asian" Islam have been critiqued by scholars such as: Shahab Ahmed, What is Islam? The Importance of Being Islamic (Princeton, 2015).

${ }^{21}$ Mudimbe, The Invention of Africa; and Mudimbe, The Idea of Africa. Responding to Mudimbe's work, Ali Mazrui has argued that Africa was "re-invented" at different historical moments due to contact with exterior "civilizations." Ali A. Mazrui, "The Re-Invention of Africa: Edward Said, VY Mudimbe, and Beyond," Research in African Literatures 36/3 (2005), 68-82.

${ }^{22}$ J.T. Olsson, "The World in Arab Eyes: A Reassessment of the Climes in Medieval Islamic Scholarship," Bulletin of the School of Oriental and African Studies 77/ 3 (2014), 487-508.

${ }^{23}$ Getachew, Worldmaking After Empire, 5.
} 
various ideological positions had begun reclaiming "a past called Africa and placing it in the foreground of their assertions of cultural identity and community." ${ }^{24}$ Pan-Africanists such as Du Bois also produced some of the earliest work in the Anglo-American academy on African history. ${ }^{25}$ In conjunction with early American cultural anthropologists, including Franz Boas and Melville Herskovits, they fashioned arguments about their community's descent from the great civilizations of Africa in order to make a claim for "full social and moral citizenship" in the United States. ${ }^{26}$ By the mid-twentieth century, a racialized view of Africa-which brought together ideas derived from Arab, Orientalist, and Pan-African strands of thought- - had become dominant in many scholarly circles. This belief was often predicated upon a notion of North African difference.

Situated at the intersection of African, Middle Eastern, and Atlantic studies, the history of Muslim Africa has long been a site through which scholars from a range of fields have struggled over the meaning of race and blackness. By making the frequently unstated assumptions about the nature of race, religion and civilization that structure the study of Africa explicit contemporary scholars who work in regions long considered ambiguous or liminal zones are now embracing the opportunity to rethink the geographic and racial underpinnings of their fields. In the process, they can also address the underlying moral and political anxieties that have shaped the study of Islam, race, and slavery in Africa. One of the most promising aspects of the new histories of race is their potential to further de-essentialize notions of African authenticity and

\footnotetext{
${ }^{24}$ Scott, "That Event, This Memory: Notes on the Anthropology of African Diasporas in the New World," Diaspora: A Journal of Transnational Studies 1/ 3 (1991), 273. For a classic study on African-American ideas about Africa, Edwin S. Redkey, Black Exodus: Black Nationalist and Back to Africa Movements, 1890-1910. (New Haven, 1969).

${ }^{25}$ In his early writings, W. E. B. Du Bois put forward a sociohistorical conception of race that tied the destiny of the "American Negro" to that of Africa. W.E.B. Du Bois, "The Conservation of Races," (Washington, DC, 1897); W. E. B. Du Bois, Africa, Its Geography, People and Products and Africa-Its Place in Modern History (Oxford 1930).

${ }^{26}$ Scott, "That Event, This Memory," 272-74. See also Robin D. G. Kelley, "'But a Local Phase of a World Problem': Black History's Global Vision, 1883-1950," The Journal of American History 86/3 (1999), 1045-77.
} 
historicize the emergence of "Africanness," "Arabness," and "Europeanness" as well as "blackness" and "whiteness."

\section{The Invention of Tradition and the Re-emergence of Race}

Reticence towards studying Islam and, later, race within African Studies began to wane at the end of the 1990s. Increased American involvement on the continent (signaled by US intervention in Somalia and the ongoing War on Terror) renewed scholarly interest in African Muslim societies. The conflicts in Rwanda and Darfur, which were often framed by the legal language of genocide, and the global outcry against the "return" of slavery in Mauritania and the Sudan also prompted scholars to begin theorizing about the roots of racial violence on the continent. These entanglements not only drew attention to the issue of race on the continent but also made African Muslims increasingly visible to American policymakers and academics. ${ }^{27}$

As this geopolitical climate was unfolding, new paradigms became dominant within African historiography. During the last two decades of the twentieth century, many Africanists turned away from the study of the pre-colonial past to focus on the colonial era. This shaped how scholars approached the history of communal identities and, in particular, ethnic formation. The 1980s and 1990s were marked by ongoing discussions over the role and impact of colonialism on the creation of African "tradition" and "native" authority. ${ }^{28}$ Similar trends occurred within South Asian studies. ${ }^{29}$ Though a number of historians emphasized the longue durée roots of ethnicity in

\footnotetext{
${ }^{27}$ Mahmood Mamdani, Good Muslim, Bad Muslim: America, the Cold War, and the Roots of Terror (New York, 2004).

${ }^{28}$ Eric Hobsbawm and Terence Ranger, The Invention of Tradition (Cambridge, 1983); Terence Ranger, The Invention of Tribalism in Zimbabwe (Gweru, 1985). For an overview of the debate over the invention of tradition, see Thomas Spear, "Neo-Traditionalism and the Limits of Invention in British Colonial Africa," The Journal of African History 44/1 (2003), 3-27.

${ }^{29}$ Nicholas B. Dirks, "The Invention of Caste: Civil Society in Colonial India," Social Analysis: The International Journal of Social and Cultural Practice 25 (1989), 42-52.
} 
Africa as well as the variety of in-group/out-group practices that characterized precolonial African societies, these disputes tended to shift scholarly attention towards the nineteenth and twentieth centuries. ${ }^{30}$ The invention of tradition literature led to path-breaking theorizing about the nature and scope of the colonial state even as it threatened to foreshorten scholarly imaginations about the African past. ${ }^{31}$

The author perhaps most associated with this historiographical trend is Mahmood Mamdani. Mamdani's arguments about the "bifurcated" nature of the colonial state, the politicization and racialization of indigeneity under colonialism, and the banality of South African apartheid became widely influential in the 1990s and 2000s. ${ }^{32}$ Mamdani's work on East Africa also reinforced a wider belief amongst scholars of the postcolonial world: namely, that racism was a product of Euro-American colonialism.

In many respects, the recent literature on race in Muslim Africa marks a decisive break from these paradigms. One can trace this shifting terrain to two influential historical works on modern Egypt. In Colonizing Egypt, Timothy Mitchell embraced Foucault's notions of power as diffuse and capillary. He argued that nineteenth-century European forms of representation inspired mimicry in Egypt decades before formal British authority was established over the Nile Valley ${ }^{33}$ Mitchell's framing of colonial representation came to influence Eve Troutt Powell's groundbreaking text, A Different Shade of Colonialism. Writing in the midst of the second

\footnotetext{
${ }^{30}$ For a book that argues for the relevancy of ethnicity as a category of analysis over the longue durée of African history, see: François G. Richard and Kevin C. MacDonald, eds., Ethnic Ambiguity and the African Past: Materiality, History, and the Shaping of Cultural Identities. (New York, 2016).

${ }^{31}$ Richard Reid, "Past and Presentism: The 'Precolonial' and the Foreshortening of African History," The Journal of African History 52/ 2 (2011), 135-155. For example, Megan Vaughan, Curing Their Ills: Colonial Power and African Illness (Palo Alto, 1991).

${ }^{32}$ Mahmood Mamdani, Citizen and Subject: Contemporary Africa and the Legacy of Late Colonialism (Princeton, 1996); Mahmood Mamdani, When Victims Become Killers: Colonialism, Nativism, and the Genocide in Rwanda (Princeton, 2001).

${ }^{33}$ Mitchell, Colonising Egypt (Berkeley, 1991).
} 
Sudanese civil war, she described Egypt's imperial role in the Nile Valley as that of "colonized colonizer." Examining the cultural production of Egyptian literary and nationalist figures, Troutt Powell showed that race and racism were as instrumental to Egypt's demands for independence as they were to its claim to rule over a black Sudan. ${ }^{34}$ In her later work, she argued that nineteenth-century Egyptian and Sudanese writers defined an Arab-Egyptian and Sudanese identity in contradistinction to a black African "other" that could be rendered a slave or "abid. ${ }^{35}$

The study of nineteenth and twentieth-century Egyptian imperialism in the Nile Valley (and the idea of the "colonized colonizer") created space for historians to pose new questions-ones that challenged the dominance of Mamdani's ideas. In his review of Troutt Powell's book, Robert Tignor asks: "Did [racial ideas amongst the Egyptian elite] arise through contact with Europe? Or did they have their own long prehistory in Egypt, based on the relations of the Egyptians to peoples to the south? $?^{36}$

One approach to these questions has been influenced by the literature on colonial hybridity. Historians and anthropologists have revealed the entanglements of multiple intellectual traditions in the nineteenth and twentieth centuries. James Brennan, for example, argues that "categories of belonging like nation, race, and ethnicity" in Dar es Salaam were influenced "as much by local understandings of hierarchy and difference as they were by colonial categories." ${ }^{37}$ As Priya Lal notes, historians are increasingly aware that "the distinction between imported and indigenous, between derived and co-produced, is not as clear as it may have seemed to a previous generation of social historians." 38 They also recognize the interplay

\footnotetext{
${ }^{34}$ Troutt Powell, A Different Shade of Colonialism, 1-26.

${ }^{35}$ Eve M. Troutt Powell, Tell This in My Memory (Palo Alto, 2012), 1-77. See Heather Sharkey, "Arab Identity and Ideology in Sudan: The Politics of Language, Ethnicity and Race," African Affairs 107/426 (2008), 21-43.

${ }^{36}$ Robert L. Tignor, "Reviewed Work: A Different Shade of Colonialism: Egypt, Great Britain, and the Mastery of the Sudan by Eve M. Troutt Powell," The International Journal of African Historical Studies 36/2 (2003), 431.

${ }^{37}$ Robert Brennan, Taifa: Making Nation and Race in Urban Tanzania. (Athens, OH, 2012), 1.

${ }^{38}$ Priya Lal, African Socialism in Postcolonial Tanzania, (New York, 2015), 36.
} 
between larger, regional macro-histories and colonial dynamics. Keren Weitzberg, for example, calls attention to older forms of imagined community based upon kinship, Islam, and nomadic life, which shaped the ways in which East Africans related to the ethnic, racial, and territorial politics of the colonial and post-colonial states. ${ }^{39}$

Yet literature on the nineteenth and twentieth century has, in a sense, circumvented a much more fraught question about the autochthony of racism in Africa and the Islamic world. While there is scholarly consensus that racial categories throughout Africa hardened over the course of the nineteenth and twentieth centuries, not all historians agree that racism has deeper roots on the continent. Rudolph Ware maintains that the precolonial slave trade in Muslim Africa has been "anachronistically racialized" and warns against reading modern ethnic and racial divisions into the deeper past. ${ }^{40}$ For Ware, modern racism has elided the pivotal contributions of West Africans to the development of Islamic theology and praxis. Although Ware's search for "authentic" Islamic practice in West Africa has come under criticism, his provocative arguments have challenged assumptions that Africa is marginal to Islam and that Islamic orthodoxy is rooted in the Arab world. ${ }^{41}$

Hall, on the other hand, argues that "there are African histories of race." ${ }^{42}$ His work examines Sahelian elaborations of race and how they changed alongside shifting political dynamics. Citing Bernard Lewis, he notes that an "identification of blackness with certain forms of slavery" occurred very early in the Middle East. ${ }^{43}$ In West Africa, pastoralists grew in power

\footnotetext{
${ }^{39}$ Keren Weitzberg, We Do Not Have Borders: Greater Somalia and the Predicaments of Belonging in Kenya (Athens, 2017).

${ }^{40}$ Ware, The Walking Qur'an, 29.

${ }^{41}$ There have been several published roundtables on Ware's book. David Robinson, "West African Islamic States and 'Antislavery' in the Walking Qur'an," Journal of Africana Religions 3/2 (2015), 177-83; Mamadou Diouf, "Introduction: Epistemology and Corporeality in West African Islam," Comparative Studies of South Asia, Africa and the Middle East 35/3 (2015), 639-41.

${ }^{42}$ Hall, A History of Race, 2.

${ }^{43}$ Hall, A History of Race, 15.
} 
vis-à-vis agriculturalists and, from the end of the sixteenth century onwards, as the Savannah empires declined, smaller Sahelian polities became increasingly dependent on North African states like Morocco. ${ }^{44}$ These dynamics, among others, encouraged Sahelian intellectuals "to reconfigure the place and origin for local Arabic- and Berber-speaking peoples in ways that rendered them a part of the wider 'white' Arab and Islamic world, but more importantly, distinct from their 'black' neighbors." ${ }^{\text {45 }}$ Fulbe and other Sahelian political thinkers, according to Hall, later internalized these genealogical constructions, which were "color coded," but not based on "observable skin color." ${ }^{\text {46 }}$ Such intellectual practices, Hall argues, had profound implications for questions of clientship and enslavement in the region, including determinations of who could and could not be enslaved.

By reconstructing a history of blackness and servitude in Morocco, El Hamel also questions assumptions that Africa was colorblind in the precolonial era. El Hamel argues that the racialization of slavery from the sixteenth to the twentieth century culminated in the development of an "internal African diaspora" in North Africa. ${ }^{47} \mathrm{He}$ hones in on the rule of Mawlay Isma'il, who reigned from 1672-1727, and his creation of a racialized army. The controversial enslavement of a long-established free Muslim population, according to El Hamel, helped to solidify the equation between blackness and slavery. ${ }^{48}$ While religious authorities in Morocco drew upon Islamic traditions to support racial hierarchies, "the history of slavery in Morocco cannot be considered separately from the racial terror of the global slave trade." ${ }^{\prime 49}$

\footnotetext{
${ }^{44}$ Hall, A History of Race, 28.

${ }^{45}$ Hall, A History of Race, 32-33.

${ }^{46}$ Hall, A History of Race, 33.

${ }^{47}$ El Hamel, Black Morocco, 5.

${ }^{48}$ El Hamel, Black Morocco, 155-184.

${ }^{49}$ El Hamel, Black Morocco, 5. See also: Chouki El Hamel, La Vie intellectuelle islamique dans le Sahel ouest africain: Une étude sociale de l'enseignement islamique en Mauritanie et au Nord du Mali. XVIe-XIXe siècles (Paris, 2002).
} 
While El Hamel and Hall focus on the Sahel and Maghreb, Glassman makes similar theoretical claims for East Africa and the Western Indian Ocean world. Though he concentrates on the nineteenth and twentieth centuries, Glassman points to the importance of longue durée intellectual practices in Zanzibar. Challenging the assumption that racial thinking in colonial and postcolonial Africa reflected only Western ideas, he argues that Zanzibari political thinkers brought their own intellectual traditions into dialogue with colonial discourses of race and ethnicity. Critical of efforts to search for a single origin of racial thought, Glassman argues that East Africans were influenced by Atlantic, Indian Ocean, and local ideas and decries the tendency to reify the distinction between "Arab" and "African."

Underlying this varied scholarship is the concept of "multiple racisms." ${ }^{\text {51 }}$ As both Hall and Glassman point out, even within nineteenth- and twentieth-century Europe and the United States, there was no singular, coherent model of race, but rather a diversity of opinions on racial mixing, descent, and biology. ${ }^{52}$ There is thus little reason to treat nineteenth-century scientific and biological racism as quintessential. While this argument obscures the ways that biological racism marked a significant epistemic rupture, it also allows one to expand the definition of racism. ${ }^{53}$ Until recently, scholars attempting to pluralize notions of racism had rarely applied the

\footnotetext{
${ }^{50}$ Glassman, War of Words, 302.

${ }^{51}$ For a discussion of the medieval origins of racial thinking in Medieval Europe, see: Geraldine Heng, The Invention of Race in the European Middle Ages (Cambridge, 2018).

${ }^{52}$ Hall, A History of Race, 10-11; and Glassman, War of Words, 8-9.

${ }^{53}$ The (now largely discredited) theory of a "post-racial" future has inspired scholarship on the afterlives of scientific racism. Concentrating on modern France, Etienne Balibar argued that there are new permutations of racism whose "dominant theme is not biological heredity, but the insurmountability of cultural differences." Etienne Balibar, "Is there a 'Neo-Racism?'” In Race, Nation, Class: Ambiguous Identities edited by Etienne Balibar and Immanuel Maurice Wallerstein (London, 1991), 21. According to Stoler, such "cultural racism" is far from new, and can be traced to the era of colonial expansion. Ann Laura Stoler, Carnal Knowledge: Race and the Intimate in Colonial Rule (Berkeley, 2002), 97.
} 
term to precolonial African contexts and most had remained firmly nestled within a so-called "Western" tradition. ${ }^{54}$

This scholarship also suggests that anti-black racism has always been a hybrid formation. While the histories examined by El Hamel and Hall predate Europe's wide-scale colonization of Africa by almost three centuries, they do not predate the European conquest of the Americas, the emergence of the Atlantic slave trade, or the rising economic and cultural influence of the West on the Islamic world. Hence, it is difficult to speak of autochthonous "African" or "Islamic" traditions of racial thought delinked from the global processes that led to the ascendance of Western Europe or the very evolution of "Europe" as a concept. Michael Gomez, on the other hand, has recently argued that historians can push the timescale of racial thinking much further into the past. Like Lewis, Gomez sees racial thought as a long-standing feature of Islamic intellectual history, but also argues that "phenotype could have been a significant social register before Islam" in the Sahel. He maintains that race-making was an inherently translocal, transregional conversation attributable to the rise of pre-Atlantic slavery, gendered notions of patrilineality, and empire-building..$^{55}$

Africanist intellectual histories of race have opened up new avenues for studying the deeper African past and present. Gomez's work, for instance, enables us to think more critically about medieval African societies and their relationship to wider regional systems. Meanwhile, scholars like Troutt Powell provide us with tools for understanding ongoing processes of racialization in the Nile Valley. A deep grounding in African intellectual history has allowed for

\footnotetext{
${ }^{54}$ Balibar argues that there are "devastating racisms, both institutional and popular, between 'nations,' 'ethnic groups,' and 'communities" in Africa, Asia, and Latin America, but does not delve greatly into the precolonial era. Etienne Balibar, "Racism and Nationalism," In Race, Nation, Class: Ambiguous Identities edited by Etienne Balibar and Immanuel Maurice Wallerstein (London, 1991), 44. See Romila Thapar, "The Image of the Barbarian in Early India," Comparative Studies in Society and History 13/4 (1971), 408-436; and John Brockington, "Concepts of Race in the Mahbhrata and Rmyana," In The Concept of Race in South Asia, edited by Peter Robb, 97-108, (Delhi, 1995). ${ }^{55}$ Gomez, African Dominion, 55.
} 
new directions in thinking about blackness and difference on both the continent and in the diaspora. Yet at the same time, these works raise a number of challenging methodological and conceptual questions: Is it mistaken to trace the genealogy of racism to a single (European) source? Did the longue durée history of slavery in the Islamic world help give form and substance to modern racial thinking? Just as some scholars argue that slavery (however varied across time and place) exists as a universal concept, can one also speak of a universal (or, alternatively, global) definition of racism?

\section{Intellectual Histories of Slavery and Abolition}

While this scholarship has opened up exciting new theoretical questions and empirical ground, there are dangers in applying the terms "race" and "racism" to such diverse settings and time periods. One inherent risk is that of overlooking African or Islamic ideas that did not directly converge with or contribute to the formation of a global color line. Writing genealogical histories often demands that one emphasize particular strands of thought to the exclusion of others. Thus, it is difficult for scholars studying the history of racial thought in Muslim Africa over the longue durée to avoid teleologies that makes the triumph of modern racism appear inevitable. What of the many paths not taken? What of non-racialized intellectual practices? There are, for example, long-standing Islamic practices that promote universalism and equality across ethnic, cultural, and linguistic divides. There are Islamic traditions of abolitionism. ${ }^{56}$ By

\footnotetext{
${ }^{56}$ William Clarence-Smith, Islam and the Abolition of Slavery (Oxford, 2006); Sean Hanretta, Islam and Social Change in French West Africa: History of an Emancipatory Community (Cambridge, 2010), 225-6; Rudolph T. Ware III, "Slavery in Islamic Africa, 1400-1800," In The Cambridge World History of Slavery, ed. David Eltis and Stanley L. Engerman (Cambridge, 2011), 47-80; Rudolph T. Ware III, "Slavery and Abolition in Islamic Africa, 1776-1905," In The Cambridge World History of Slavery, ed. David Eltis and Stanley L. Engerman (Cambridge, 2011), 344-72; Chris Gratien, "Race, Slavery, and Islamic Law in the early modern Atlantic: Ahmad Baba alTinbukti's treatise on enslavement," The Journal of North African Studies 18/3 (2013), 454-68; Timothy Cleaveland, "Ahmad Baba al-Timbukti and His Islamic Critique of Racial Slavery in the Maghrib," The Journal of North African Studies 20/1 (2015), 42-64; Ware, The Walking Qur'an, 116.
} 
the same token, one can speak about multiple global histories of race, not all of which were destined to converge with the rise of Western scientific racism.

The pervasiveness of white supremacy in the present casts a long shadow over our understanding of the past. ${ }^{57}$ Nevertheless, anti-black prejudice need not be seen as an inexorable part of world history. There are less teleological ways to interpret the recent theoretical turn towards race in African studies. The new work on slavery and race in West Africa and the Maghreb can help to challenge linear, triumphalist narratives. Rather than a unified or continuous story, the history of race is marked by a reformulation of successive, yet distinct "racial" projects. ${ }^{58}$ According to Hall, for several centuries prior to French colonization of the Niger Bend, blackness "rendered one vulnerable to legitimate enslavement, to political domination, and to other kinds of legal disability."59 Yet his work simultaneously suggests that a racial project of anti-blackness was not continuous, inevitable, or unchallenged in the Sahel. ${ }^{60}$

If one acknowledges that there have been several different "racial" projects in Muslim West Africa, it also becomes easier to reconcile apparent disagreements between scholars. Reading Hall's work alongside that of Ware, one can see how anti-blackness in the Sahel may have waxed and waned over the course of the early modern and modern eras. Ware, for example, describes the revolution of Al-Amaani Sulayman Baal and 'Abd al-Qadir Kan between 1776 and

\footnotetext{
${ }^{57}$ Paul Cohen notes that: "the degree to which the meaning of the past is held hostage to [a] as yet undefined future would appear to belie the common view among historians that, as one of us has enunciated it, 'what comes after cannot influence what came before." Paul Cohen, History in Three Keys: The Boxers as Event, Experience and Myth (New York, 1997), 62.

${ }^{58}$ The sociologists Michael Omi and Howard Winant define a racial project as follows: "A racial project is simultaneously an interpretation, representation, or explanation of racial identities and meanings, and an effort to organize and distribute resources (economic, political, cultural) along particular racial lines." Michael Omi and Howard Winant, Racial Formation in the United States (New York, 2015), 125.

${ }^{59}$ Hall, A History of Race, 22

${ }^{60}$ Hall, A History of Race, 22.
} 
1806. According to Ware, Hasani warriors ${ }^{61}$ in Fuuta Tooro were driven from the banks of the Senegal River by the Amirs al-Muminin, ${ }^{62}$ who abolished slavery and instituted greater equality between all who memorized the words of the Quran. Fuuta oral traditions remember Al-Amaani 'Abdul Qadir Kan declaring: “the Muslim was anyone who said, 'La ilaha illa Allah' even if it was pronounced 'ra ira'a ira Arra'...the point of the story is that anyone willing to profess Islam should be freed." 63 Ware perhaps overstates the universalism of Al-Ammani's rhetoric (slavery was still very much defined by the cultural boundaries of Pulaar identity). Yet he also upends conventional histories of abolitionism by showing that 'the enslavement of bearers of the Qur'an and their families served as proximate cause for revolt." ${ }^{\prime 64}$ One way to interpret this episode is to see it as an overturning of the pre-existing socio-political order. ${ }^{65}$

The differences between Hall and Ware are partly attributable to their choice of sources. Hall makes use of the Arabic language collections, which were newly available in Timbuktu, as well as French sources stored in local archives across Mali. Ware, on the other hand, bases many of his claims on oral interviews conducted in Wolof and French as well as "participant observation in Senegalese Muslim social and intellectual life." ${ }^{\prime 66}$ Despite differing methodologies and epistemologies at work in their scholarship, it is not impossible to imagine reconciling their seemingly conflictual claims.

\footnotetext{
${ }^{61}$ The Hasani warriors referenced by Ware were members of the Beni Hassan, a warrior caste who claimed a right to rule on the basis of their putative foreign origins. The Beni Hassan trace their lineage to Arabia, separating themselves from those they call the Haratin. For a discussion of Haratin movements for emancipation and social equality, see Khaled Mohamed Esseissah, “'Making a Way Out of No Way:' Haratin Muslims' Initiatives to Gain Respectability in Post-Emancipation Mauritania,” (PhD Diss, Indiana University, 2019).

${ }^{62}$ A title distinguished by its holders' claim to be a legitimate ruler of the Muslim community.

${ }^{63}$ Ware, The Walking Quran, 114-5.

${ }^{64}$ Ware, The Walking Quran, 111-112.

${ }^{65}$ Ware, "Slavery and Abolition in Islamic Africa, 1776-1905," 344-372.

${ }^{66}$ Ware, The Walking Quran, 12.
} 
As Ware and even Hall's scholarship demonstrates, the resurgence of Arab chauvinism in the twentieth century does not necessarily relate to an unbroken history of anti-blackness in Muslim West Africa ${ }^{67}$ Together, this scholarship suggests that anti-black discrimination as well as the valorization of blackness existed at different times and places throughout Africa. Thus, it would be a mistake to think in terms of a linear history leading inexorably towards modern scientific racism. When read together, this scholarship also calls into question liberal assumptions about human societies that posit collective, if uneven, progress towards the elimination of inherited racist beliefs.

\section{Translating Race}

A related question is whether race and racism are the right analytical terms with which to discuss the experiences of African societies prior to colonialism. This is not simply a matter of semantics. Translations are often politically fraught and different conceptual vocabularies can be justified on different grounds. Race itself is a part of a European lexicon, which raises questions as to its applicability across time and space. One must critically reflect on the challenges involved in translating African and Islamic terms (such as nubi or 'abid) into the ostensibly universal language of the social sciences (which is deeply derivative of European thought). ${ }^{68}$ Using this vocabulary to describe modes of exclusion in Africa conjures up comparisons with racism in the Atlantic World. At the same time, there is a risk of collapsing a variety of different

\footnotetext{
${ }^{67}$ For other scholarship that ties Islam in West Africa to pro-black racial projects, see: Cheikh Babou, Fighting the Greater Jihad: Amadu Bamba and the Founding of the Muridiyya of Senegal, 1853-1913 (Athens, 2007); and Mamadou Diouf, "The Senegalese Murid Trade Diaspora and the Making of a Vernacular Cosmopolitanism," Public Culture 12/3, translated by Steven Rendall (2000), 679-702.

68 "To challenge the model of "rough translation," as Dipesh Chakrabarty argues, "is to pay critical and unrelenting attention to the very process of translation." Dipesh Chakrabarty, Provincializing Europe: Postcolonial Thought and Historical Difference (Princeton, 2000), 17. On the problem of transforming historically specific phenomenon into social scientific concepts with universal applicability, see: Jack Goody, Technology, Tradition and the State in Africa, (New York, 1971), 1-39.
} 
phenomena under a common rubric and thus naturalizing anti-black racism as a universal and/or transhistorical phenomenon.

For Hall and El Hamel, the lack of a meta-term for "race" in Muslim Africa does not preclude its use. According to El Hamel: "Blacks in Morocco have been marginalized for centuries...The fact that Arabic literature is not consistent in the terms it uses...does not mean that race (for example, a racialized other) did not exist in Arabic thought and Islamic culture and history." ${ }^{69}$ Hall believes that rejecting the use of the word race for the premodern and nonWestern world is a kind of "nominalism," which prevents comparisons from being drawn between historically specific forms of racial thinking. ${ }^{70}$ He points to similar concepts within the Muslim world that together could be described as racism.

While broadening such terms allows for useful comparisons to be made across different historical epochs and cultural settings, it can also invite conflations. The issue of anachronism looms large within this scholarship. It is unclear whether the concept of race adequately captures the varied intellectual traditions across the Sahel that have emphasized different, if related forms of belonging/exclusion (such as "genealogy, or primacy"). ${ }^{71}$ According to Sean Hanretta, due to an overreliance on Arabic sources and gaps in the historical record, "the intellectual history of those who were often most harmed by racism" may be difficult (if not impossible) to reconstruct. ${ }^{72}$ These gaps make it easier for historians to recover how those in a position of power sought to identify others than how groups often identified themselves. Moreover, very

\footnotetext{
${ }^{69}$ El Hamel, Black Morocco, 99.

${ }^{70}$ Hall, A History of Race, 10.

${ }^{71}$ James Searing, "Reviewed Work(s): A History of Race in Muslim West Africa, 1600-1960, by Bruce Hall," The International Journal of African Historical Studies 45/2 (2012), 320.

${ }^{72}$ Sean Hanretta, "Bruce S. Hall. A History of Race in Muslim West Africa, 1600-1960," American Historical Review 118/3 (2013), 976.
} 
different epistemes governed African Muslim societies prior to the nineteenth century. ${ }^{73}$ In precolonial Africa what we would refer to today as "religious" (as opposed to "racial") chauvinism was frequently a more important factor in the creation and maintenance of hierarchies. ${ }^{74}$ In nineteenth-century Northeast Africa, far more significant than "race" or “ethnicity" was the question of who was (or was not) a Muslim and a pastoralist. Such distinctions, which were sometimes tied to ideas of skin color and descent, were intimately linked to enslavability. ${ }^{75}$

In many respects, debates about the comparability and universality of race and racism across space and time mirror long-standing debates amongst historians of slavery. Since the 1960s, scholarship on African slavery has been grounded in explicit and implicit comparisons with the Atlantic World. As Frederick Cooper pointed out in 1979, though Africanists and Americanists have often studied "in isolation from one another," each field has used the other as a foil and antipode. ${ }^{76}$ This has led Africanists to raise a number of comparative questions: Is the term slavery applicable to all African contexts? Was African slavery more benign than other types of bondage? Challenging the Atlantic paradigm, Susan Miers and Igor Kopytoff have called into question the "person-as-property" model, suggesting that African slavery be understood along a continuum of belonging (rather than in contradistinction to freedom). ${ }^{77}$ The

\footnotetext{
${ }^{73}$ Louis Brenner, Controlling Knowledge: Religion, Power, and Schooling in a West African Muslim Society (Bloomington, 2001).

${ }^{74}$ For the construction of "religion" as a modern concept, see: Talal Asad, Formations of the Secular: Christianity, Islam, Modernity (Palo Alto, 2003).

${ }^{75}$ Weitzberg, We Do Not Have Borders, 29.

${ }^{76}$ Cooper argues: "Americanists have found African slavery to be a conveniently benign foil against which the exploitation and degradation of American slavery stand out. Africanists have been anxious to dissociate slavery in Africa from its bad image in the Americas." Frederick Cooper, "The Problem of Slavery in African Studies," The Journal of African History 20/1 (1979), 103.

${ }^{77}$ Ali A. Mazrui, "The Black Arabs in Comparative Perspective: The Political Sociology of Race Mixture," In The Southern Sudan: The Problem of National Integration, edited by Dustan M. Wai, 47-82. (London, 1973); Suzanne Miers and Igor Kopytoff, eds. Slavery in Africa: Historical and Anthropological Perspectives (Madison, 1977); James Watson, "Slavery as an Institution: Open and Closed Systems," In Asian and African Systems of Slavery, edited by James L. Watson, 1-15. (Berkeley, 1980).
} 
questions posed by Africanist scholars have also echoed broader debates within the field of slavery studies over the nature of freedom and the distinctions between different types of bondage (such as field vs. domestic slavery). ${ }^{78}$ Oftentimes, such debates hinged on whether slavery could be considered a universal, structural condition. ${ }^{79}$ These discussions have given rise to a range of transnational studies, which have offered frameworks for understanding bondage as a social scientific concept and comparing slavery across different time periods, societies, and regions. $^{80}$

These issues are relevant to contemporary scholars of Muslim Africa, who are posing analogous questions about racism, a form of oppression inextricably linked to slavery. Historians of race face similar problems of conceptual slippage as they study how ideas and structures adjacent to modern racism operated in non-Western and premodern contexts. Yet, unlike slavery (which is widely considered to be an ancient practice), racism has long been seen as a profoundly modern institution. ${ }^{81}$

\footnotetext{
${ }^{78}$ For more on the problem of freedom within slavery studies, see Thomas C. Holt, The Problem of Freedom: Race, Labor, and Politics in Jamaica and Britain, 1832-1938 (Baltimore, 1992); Eric Foner, The Story of American Freedom (New York, 1999); and Walter Johnson, “On Agency," Journal of Social History 37/1 (2003), 113-24.

${ }^{79}$ Orlando Patterson, for example, has argued that it is possible to speak of a universal concept of slavery. He defines slavery as a kind of "social death" ("the permanent, violent domination of natally alienated and generally dishonored persons"). Orlando Patterson, Slavery and Social Death: A Comparative Study (Cambridge, MA, 1982), 13. According to Gwynn Campbell, a scholar of the Indian Ocean world, Patterson still treats an Atlantic paradigm as quintessential. Gwynn Campbell, "The Question of Slavery in Indian Ocean World History," In The Indian Ocean: Oceanic Connections and the Creation of New Societies, edited by Abdul Sheriff and Engseng Ho, 123-49. (London, 2014), 134.

${ }^{80}$ Patrick Manning, Slavery and African Life: Occidental, Oriental and African Slave Trades (Cambridge, 1990); Lydia Wilson Marshall, ed. The Archaeology of Slavery: A Comparative Approach to Captivity and Coercion (Carbondale, 2014); Jeff Forret and Christine E. Seares, eds., New Directions in Slavery Studies: Commodification, Community, and Comparison (Baton Rouge, 2015).

${ }^{81}$ Nwokeji notes: "Slavery was an ancient institution known to have been widespread in the Old World. As part of the Old World, therefore, African societies practiced slavery; it would have been an anomaly if slavery did not exist on the continent." G. Ugo Nwokeji, "Slavery in Non-Islamic West Africa, 1420-1820," in The Cambridge World History of Slavery, Vol. 3: AD 1420-AD 1804, eds. David Eltis and Stanley L. Engerman, 81-110. (Cambridge, 2011), 81 .
} 
Yet another option is to "abandon race altogether as a category of analysis." 82 Glassman advocates for seeing racism along a continuum of thought "that categorizes humanity via metaphors of descent." Nationalism, ethnicity, and racism are analytically related, he argues, and their differences are ones of "degree, not kind." ${ }^{\text {" }}$ He highlights how virtually any form of categorization based on descent (including Pan-African nationalism) can become racialized and exclusionary. Glassman's insights are important as they help to historicize Pan-African nationalism and highlight African contributions to the formation of ethnic and racial thought (which have often been thought of as colonial inventions). In treating ethnicity, racism, and nationalism as variations of groupness (a concept borrowed from Rogers Brubaker), he also calls into question the nationalist paradigm that treats ethnicity and race as divisive, and the nationstate as inherently liberatory. ${ }^{84}$ Nevertheless, the concept of groupness can just as easily obscure both the historical specificity of certain kinds of racism and the important distinctions between race and other forms of difference-making. As Patricia Lorcin argues, nationalism "does not necessarily degenerate into racism or the violence, verbal or physical, that the concept of racism implies." 85 It also fails to overcome the assumptions of anti-blackness buried in the analytic concept itself.

There are, indeed, valid reasons to use the terms race and racism to describe the institutionalized forms of anti-blackness that emerged in Africa over the last few centuries. These terms, however, index fraught disciplinary disputes within the American academy. Since the 1970s, scholars across varied fields, but particularly Islamic and African-American studies, have

\footnotetext{
${ }^{82}$ Glassman, War of Words, 302.

${ }^{83}$ Glassman, War of Words, 11.

${ }^{84}$ Rogers Brubaker, Ethnicity Without Groups (Cambridge, 2004); and Glassman, War of Words, 15.

${ }^{85}$ Patricia M. E. Lorcin, “Jonathon Glassman. War of Words, War of Stones: Racial Thought and Violence in Colonial Zanzibar," The American Historical Review 117/5 (2012), 1536.
} 
debated Islam's relationship to African culture and civilization. In his widely cited 1971 text,

Race and Colour in Islam, Bernard Lewis argued that racism was endemic to Muslim societies, taking aim at what he saw as the pernicious myths of Arnold Toynbee and Malcolm X. ${ }^{86}$ In contrast to Lewis' Orientalist thinking, the Kenyan scholar Ali Mazrui maintained that Islam was fairly assimilative and inclusive and, unlike the American system, "permitted considerable racial cooptation." ${ }^{87}$ In the late 1980s, Mazrui became enmeshed in a heated debate with the Nigerian writer and Nobel Prize laureate, Wole Soyinka, who accused him of denigrating "African authentic spirituality" in his popular documentary, The Africans: A Triple Heritage. Islam and Christianity, according to Soyinka, were "seductive superstitions imported into, or forced down the throat of the African continent." ${ }^{" 88}$ Questions regarding the "authenticity" of Islam and the position of "Arabs" within the African continent reemerged a decade later, during the contentious debates over another documentary: Henry Louis Gates Jr.'s Wonders of the African World ${ }^{89}$ What united these disparate debates was the assumption that Islam, Christianity, and Africa represented self-contained civilizations, each with its own distinctive cultural norms and legal practices. As Glassman notes, these disputes were also "structured by the essential racial binary of African versus Arab." ${ }^{90}$ Unfortunately, such depictions have reinforced the idea of a

\footnotetext{
${ }^{86}$ Bernard Lewis, Race and Colour in Islam (New York, 1971). One of Lewis' fiercest critics was Edward Said. See their 1982 exchange in the New York Review of Books. Bernard Lewis, "The Question of Orientalism," The New York Review of Books (June 24, 1982) and Edward Said and Oleg Grabar, reply by Bernard Lewis, "Orientalism: An Exchange," (August 12, 1982). For the wider prevalence of missionary and colonial assumptions in writings about Islamic slavery, see: McDougall, "Discourse and Distortion."

${ }^{87}$ The Arab lineage system, Mazrui argues, enabled those with darker skin to be "admitted to higher echelons as full members - provided that the father was an Arab." Mazrui, "The Black Arabs in Comparative Perspective," 56.

${ }^{88}$ Wole Soyinka, "Religion and Human Rights," Index on Censorship 17/5 (May 1988), 82-85.

89 "The Debate: Wonders of the African World," 1; Mazrui, "A Preliminary Critique of the TV Series by Henry Louis Gates, Jr," 5-6; Gates, "A Preliminary Response to Ali Mazrui's Preliminary Critique of 'Wonders of the African World," 10-14; and Soyinka, "Ali Mazrui and Skip Gates' Africa Series," The Black Scholar 30/1 (2000): 7. See also, Lansiné Kaba, "The Atlantic Slave Trade was Not a "Black on Black Holocaust," African Studies Review 44/1 (2001), 1-20.

${ }^{90}$ Glassman, War of Words, 300.
} 
cultural and even racial divide between Africans deemed indigenous and Muslims who are seen, at best, as culturally foreign.

\section{Race as a Universal Category}

These two problematics--that of teleology and translation--hinge on a larger question. Scholars of race in Muslim Africa have yet to resolve a fundamental ambiguity: On one hand, the development of racial thought in Africa may be part and parcel of "the growth of a single racism" tied to the creation of a modern world economy. ${ }^{91}$ On the other hand, there may be nonderivative, autochthonous intellectual traditions that (though distinct from Western pseudoscientific ideologies) can be meaningfully understood within the rubric of "racism." The failure to address this ambiguity opens the door for widely different interpretations of the comparative significance of this recent work.

It is our contention that scholars such as Hall, Troutt Powell, El Hamel, Glassman, and Ware are studying different moments of racialization, but their analyses need to be situated within a global framing. Africanist scholarship takes on very different meaning when viewed on a global scale and in dialogue with a wider set of literature on the Atlantic world. Ware has provocatively suggested that the emergence of racism in the Atlantic and Mediterranean worlds occurred concurrently and can best be understood "as the growth of a single racism" linked to modernity.$^{92}$ Pierre has also criticized African diaspora studies for ignoring continental Africa and overlooking the "mutual construction of global Black identities on both sides of the Atlantic. ${ }^{{ }^{93}}$ By the same token, El Hamel suggests that we not only consider the influence of the Atlantic system on Africa, but also the ways in which the African, Mediterranean, and Indian

\footnotetext{
${ }^{91}$ Ware, The Walking Qur'an, 30.

${ }^{92}$ Ware, The Walking Qur'an, 29-30.

${ }^{93}$ Pierre, The Predicament of Blackness, xiv.
} 
Ocean worlds may have shaped the Atlantic economy and its racialized culture. ${ }^{94}$ Similarly, Michael Gomez (who has redressed Africa's absence within global history) has recently argued that the Savannah and Sahel's "borderland' quality" enabled "mutual exchange over millennia" that facilitated a centuries-long, trans-local conversation about race. ${ }^{95}$

These brief, yet tantalizing comments point to the need to understand modern racism as an overdetermined, transcontinental process that brought together multiple intellectual traditions. They also indicate that the history of modern racism cannot be divorced from a broader understanding of the regional and global political economy. One must consider the forms of economic integration that allowed ideas of race to travel and become normalized, spreading across the Atlantic, Saharan, Mediterranean, and Indian Ocean worlds.

Racism emerges when the raw material of racial thought crystallizes into racialized sociopolitical orders. World-systems theorists and black political economists have argued that the globalization of anti-Black racism is a unique product of modernity, an outgrowth of the transcontinental slave trade and global capitalism. ${ }^{96}$ Glassman is critical of scholars who, drawing upon Immanuel Wallerstein, tie racism "mechanistically to the structures of global capitalism" and hence remove race "...from the realm of intellectual history." 97 Yet for many critical race theorists, racism is not purely ideational. Rather, it is a historical, structural process whose emergence comes only "after the imperialist expansion of Europe to the New World and

\footnotetext{
${ }^{94}$ El Hamel, Black Morocco, 133-4, 154. Glassman makes a similar claim. Glassman, War of Words, 283. Yet neither scholar expands at length on these provocative statements.

${ }^{95}$ Gomez, African Dominion, 55. Whereas Abu-Lughod largely overlooks Africa's contributions to world systems prior to the sixteenth century, Gomez recenters early and medieval Africa. For an engaging discussion on Africa's place in the historiography on world history, see: Gomez, African Dominion, 11-12; Janet Abu-Lughod, Before European Hegemony: The World System A.D. 1250-1350 (New York, 1991).

${ }^{96}$ For a discussion on the relationship between race and the history of capitalism, see Peter James Hudson, "The Racist Dawn of Capitalism: Unearthing the Dawn of Bondage.” Boston Review (March 14, 2016).

${ }^{97}$ Glassman, War of Words, 10.
} 
Africa." 98 One can look to the political economists of the African Diaspora, who have a long scholarly tradition of wedding analyses of global capitalism and racism. This tradition dates back to the publication of Eric Williams' 1944 text, Capitalism and Slavery. For example, Williams famously asserted that: "Slavery was not born of racism; rather, racism was the consequence of slavery" and, together, they created the foundations of modern capitalism. ${ }^{99}$ Almost forty years later, Cedric Robinson concurred that the globalization of blackness (as a concept synonymous with slavery and poverty) was tied to the emergence of world-spanning empires emanating from northwestern Europe. ${ }^{100}$

Racism is inextricably linked to the rise of modernity. Yet we should be wary of “equating 'Europe' and 'modern." ${ }^{101}$ For Wallerstein, Walter Rodney, and many of their followers and contemporaries, the driving force behind the creation of a world economy was the expansion of European powers, the conquest of the so-called "New World," and the development of societies organized around production for the transatlantic market. ${ }^{102}$ The centrality of Europe and the Atlantic world to the making of the modern world has, nevertheless, been challenged. Scholars like Janet Abu-Lughod have shown that Africa and Asia were already part of an existing world system centered on the Islamic heartlands as early as the thirteenth century. ${ }^{103}$ Racialized modernity is layered atop these older histories.

\footnotetext{
${ }^{98}$ Bonilla-Silva, "Rethinking Racism," 473.

${ }^{99}$ Williams, Capitalism and Slavery, 7. His thesis sparked a long-standing debate over the links between racial prejudice and slavery.

${ }^{100}$ Cedric Robinson, Black Marxism: The Making of the Black Radical Tradition (Chapel Hill, 1983).

${ }^{101}$ Herman L. Bennett, African Kings and Black Slaves: Sovereignty and Dispossession in the Early Modern Atlantic (Philadelphia, 2018), 17.

102 Immanuel Wallerstein, The Modern World System, 3 vols. (New York, 1974-1989); Walter Rodney, How Europe Underdeveloped Africa (London, 1972); and. Joseph E. Inikori, "Africa and the Globalization Process: Western Africa, 1450-1850," Journal of Global History 2/1 (2007): 63-86.

${ }^{103}$ Western Europe, according to Janet Abu-Lughod, emerged from the periphery of this world system in the sixteenth century. Abu-Lughod, Before European Hegemony.
} 
The enduring and globalized impact of scientific racism makes it difficult to retrieve older histories that converged with, but were not reducible to Western racial science. A global history of racism must be a story of possibility, not inevitability that depicts race as an historical category rather than a naturalized given. Historians of the Atlantic world have offered models for thinking about cultural and intellectual exchange that center coevality and intercommunication without privileging European metanarratives or evolutionary paradigms. Scholars such as Herman Bennett, John Thornton, Linda Heywood, James Sweet, and Mariana Candido have shown that centuries of exchange gave birth to creole societies on both sides of the Atlantic. ${ }^{104}$ Studying these societies has highlighted the extent to which processes of racialization were contested (and continue to be contested) in the wake of the massive structural change produced by the slave trade, emancipation, colonialism, and independence. ${ }^{105}$ This work has also shown the contributions of Africans to the creation of the Black Atlantic and the making of modernity. The racialized culture that emerged around the Atlantic economy reflected a past that "tacked between African and European history" rather than being absorbed into a telos of European domination. $^{106}$

Instead of placing European and Islamic/African practices in implicit or explicit comparison or creating narratives that treat the rise of nineteenth-century scientific racism as inexorable, historians are beginning to imagine a world "shaped by a dialogue among numerous other coeval interlocutors of unequal power and unequal access to the means of

\footnotetext{
${ }^{104}$ John K. Thornton, Africa and Africans in the Making of the Atlantic World (Cambridge, 1992); James Sweet, Recreating Africa: Culture, Kinship, and Religion in the African-Portuguese World, 1441-1770 (Chapel Hill, 2003); Linda Heywood and John K. Thornton, Central Africans, Atlantic Creoles, and the Foundations of the Americas, 1585-1660 (Cambridge, 2007); Mariana P. Candido, An African Slaving Port and the Atlantic World: Benguela and its Hinterland (Cambridge, 2013); Bennett, African Kings and Black Slaves

${ }^{105}$ For an argument about analyzing racism as a structural, rather than purely ideational phenomenon, see BonillaSilva, "Rethinking Racism."

${ }^{106}$ Bennett, African Kings and Black Slaves, 11.
} 
communication." ${ }^{107}$ One of the biggest shortcomings within much of the new literature on race in Muslim Africa is its attempt to locate autochthonous African intellectual traditions that existed prior to processes of cross-fertilization and hybridity. Ultimately, it is misleading to speak of "Western," "Islamic," or "African" histories of race, especially during periods when a world economy, linked in part to the growth of slavery, was emerging. Historians are instead faced with the challenge of telling a story of simultaneity, dialogue, and exchange across African Muslim societies that were part of larger Atlantic, Mediterranean, and Indian Ocean world systems spanning centuries. They are handicapped by having to use social scientific categories derived from a Western lexicon. ${ }^{108}$ The challenge awaiting scholars is not only to recognize the existence of a multiplicity of discourses on race and difference, but also to situate discursive and epistemic shifts within a changing global political economy that has never been exclusively centered on Europe or the Americas.

\section{Conclusion: Deprovincializing Race}

The insights and gaps within recent scholarship on race in Africa point towards two future research agendas. Historians of Muslim African societies have suggested that the origins of anti-blackness do not lie solely in the European or Atlantic worlds. There is a need to study the connections between anti-blackness in African history and racism within European/Atlantic history without rendering the former derivative of the latter. Secondly, the use of intellectual and cultural history to examine anti-blackness in Muslim Africa highlights the distinction between race-thinking and racism. Anti-black discourses as well as rhetoric valorizing blackness can be

\footnotetext{
107 J. Lorand Matory, "From "Survival" to "Dialogue": Analytic Tropes in the Study of African-Diaspora Cultural History." In Transatlantic Caribbean: Dialogues of People, Practices, Ideas, edited by I. Kummels, C. Rauhut, S. Rinke, and B. Timm, 33-55. (Bielefeld, 2014), 50.

${ }^{108}$ Goody, Technology, Tradition and the State in Africa, 1-39.
} 
found in Islamic texts for most time periods, dating as far back as antiquity. ${ }^{109}$ Yet the presence of racial discourse is not synonymous with racism as a structural condition. Barbara and Karen Fields show that even as race-thinking loses its cultural salience, the consequences of racism as a structural condition continue to be felt. ${ }^{110}$ Greater attention to race in African and Muslim contexts can help us better apprehend how racial thinking does (or does not) coalesce into racism. It can also enrich our understanding of the links between slavery and the creation of racial orders.

Reading across the fraught disciplinary boundaries of African Diaspora, Middle Eastern, Islamic, and African studies opens up avenues for historicizing racialization in non-Western contexts and outside the Manichean binaries of black versus white. ${ }^{111}$ Studying African intellectual history allows us, for example, to understand the shifting meaning of the word Sudani from a slur in the early twentieth century to a term embodying nationalist visions only a few decades later. ${ }^{112}$ Atlantic history, on the other hand, enables us to appreciate the impact of Afro-Brazilian returnees on the making of Nigerian and Yoruba ideas of ethnic and racial difference. ${ }^{113}$ Africanist historians can contribute to a better understanding of race-making in the Atlantic world. Meanwhile, African Diaspora scholarship can reveal the importance of the Atlantic world to African and Islamic intellectual, social, and political practices. ${ }^{114}$ The theoretical architecture developed by critical race theorists can also lead to a more robust and

\footnotetext{
${ }^{109}$ Jackson, Islam and the Blackamerican, 102-108.

${ }^{110}$ Fields and Fields, Racecraft. See: Stuart Hall, "Race--The Sliding Signifier," In The Fateful Triangle: Race, Ethnicity and Nation, edited by Kobena Mercer. (Cambridge, 2017), 31-79.

${ }^{111}$ For a discussion of the recent study of race in Middle Eastern Studies, see: Erin Pettigrew, "Histories of race, slavery and emancipation in the Middle East," Mediterranean Politics 25/4 (2020), 528-36.

${ }^{112}$ Heather Sharkey, Living With Colonialism: Nationalism and Culture in the Anglo-Egyptian Sudan (Berkeley, 2003), 16-40.

${ }^{113}$ Matory, "The English Professors of Brazil."

${ }^{114}$ Michael A. Gomez, Exchanging Their Country Marks: The Transformation of African Identities in the Colonial and Antebellum South (Chapel Hill, 1998).
} 
sophisticated understanding of the materiality and embodied experiences of race-making across varied contexts.

Integrating these fields around the study of race demands abandoning an area studies paradigm, which reifies knowledge about particular regions of the world, and adopting global and regional frameworks that emphasize coevality, simultaneity, and exchange. This approach would allow us to see the development of modern racism as part and parcel of a global history that knitted together the Atlantic, Saharan, Mediterranean, and Indian Ocean worlds. Assumptions about the relative isolation of Africa and powerlessness of Africans have too often rendered such historical processes invisible. At the same time, discussions about the so-called "Arab" or "Islamic" role in the slave trade have frequently devolved into crude comparative debates that have pitted different groups against one another. ${ }^{115}$ In the age of the "War on Terror," it is important to avoid analyses that converge with or mask an Islamophobic agenda. Yet one must also avoid slipping into a shallow form of anti-colonialism that obscures the multiple origins of inequality. The challenge is to write global and regional histories that are not underpinned by Eurocentric teleologies or crude and simplistic comparative frameworks.

Investigating the history of racism from a global perspective shows that anti-blackness is not a static, transhistorical, or universal category, but rather a contingent historical process that developed over time and amidst resistance. Blackness came to be constructed both in relation to whiteness and in relation to Arab, African, and Islamic ideas of difference. Rather than attribute different "racisms" to different "traditions," we can see racism in its various local, regional, and global manifestations as a nexus of particular socio-economic and political forces. Local

\footnotetext{
${ }^{115}$ See, for example, the recent controversy over Georgetown professor Jonathan Brown's lecture on "Muslim slavery." Stauss, "Georgetown Professor Under Fire for Lecture About Slavery and Islam." See also, Jonathan A. C. Brown, Slavery and Islam (London, 2019). Also, for the historical perspective, see: McDougall, "Discourse and Distortion."
} 
instances of racialization were tied to global hierarchies. At the same time, it is important to acknowledge that a significant epistemological shift occurred in the nineteenth century. The gradual and uneven abolition of slavery was accompanied by a hardening of the global color line, the rise of scientific racism, and the large-scale colonization of Africa. In the process, blackness became a signifier of denigration, obscuring many previous political, cultural, and socioeconomic ways of being. ${ }^{116}$ At their best, new histories of race can show us that despite its global reach, overdetermined foundations, and longevity, anti-black racism has never gone uncontested. The history of resistance is equally global in scope, linked as it is to Euro-Atlantic, Christian, indigenous, and Afro-Islamic practices. Much more work needs to be done to account for the coexistence of anti-black ideologies alongside those that championed blackness and those that did not find race to be a relevant category at all. Racism may have developed and coalesced around an increasingly global economy that emerged after the end of the fifteenth century. Yet anti-racist resistance has also evolved and accrued over time, spanning multiple, interconnected traditions.

Finally, in order to understand the implications of using race in African history, it is necessary to reflect on the work that it does in historical narratives. The challenge is to situate intellectual histories of race within the political economies that reproduce inequalities simultaneously on global, regional, and local scales. The methods of intellectual history have provided new ways for historians to examine how historical actors have deployed race in order to make difference. Yet political economy offers intellectual historians a means of situating their narratives within the structures that both opened and foreclosed the range of possibilities of

\footnotetext{
${ }^{116}$ Bennett, African Kings and Black Slaves, 30-31.
} 
historical actors. ${ }^{117}$ The turn to intellectual history has allowed historians to recover African epistemologies. In the process, it has countered a tendency of some historians to make Africans legible by rendering them as rational actors according to universal narratives of development, which were constructed outside of the continent. African intellectual history deprovincializes Africa by refusing universalist narratives thereby preventing social scientists from rendering African cases as inevitable stories of deviation or lack. ${ }^{118}$ Yet the potential of an African history of ideas can only be reached if historians resist the urge to search for histories of predetermined concepts and instead allow concepts derived from the sources that make up the African archive to speak and guide our research. ${ }^{119}$ The incorporation of African concepts into the history of ideas allows African history to become constitutive and coeval with global history.

\footnotetext{
${ }^{117}$ Frederick Cooper, "Possibility and Constraint: African Independence in Historical Perspective," Journal of African History 49/2 (2008), 167-196.

${ }^{118}$ Chakrabarty, Provincializing Europe, 17

${ }^{119}$ See for an example of this approach, Wendell Hassan Marsh, "Reading with the Colonial in the Life of Shaykh Musa Kamara, a Muslim Scholar-Saint,” Africa 90/3 (2020), 604-624.
} 